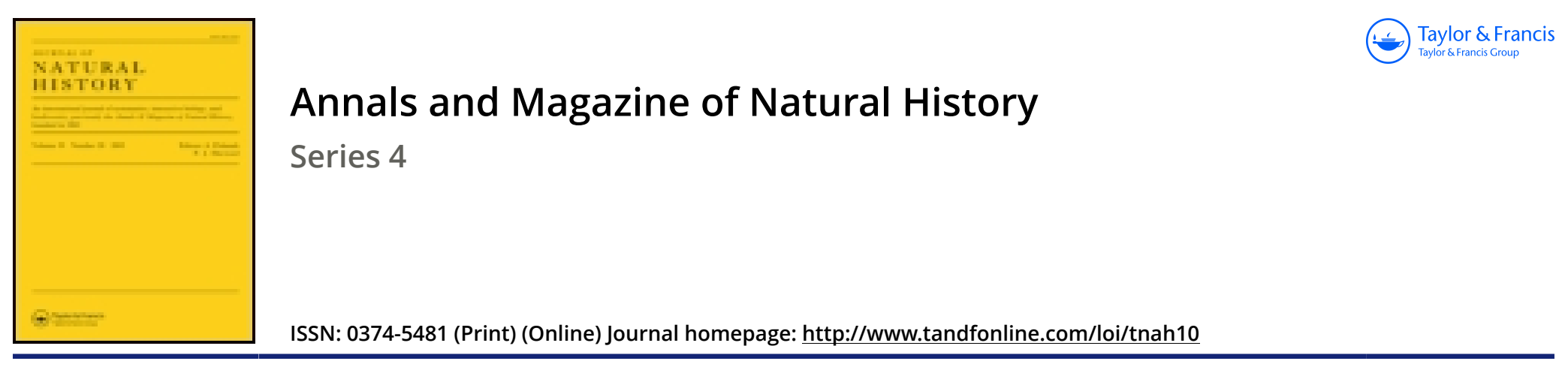

\title{
On the development of the Phragmostracum of the Cephalopoda, and on the zoological relations of the ammonites to the Spirulæ
}

\section{Munier-Chalmas}

To cite this article: M. Munier-Chalmas (1874) On the development of the Phragmostracum of the Cephalopoda, and on the zoological relations of the ammonites to the Spirulæ, Annals and Magazine of Natural History, 13:74, 183-185, DOI: 10.1080/00222937408680836

To link to this article: http://dx.doi.org/10.1080/00222937408680836

曲 Published online: 13 Oct 2009.

Submit your article to this journal $\pi$

Џlll Article views: 1

Q View related articles $\sqsubset$ 
Kogia Floweri, from Mazatlan, Lower California-described from a specimen consisting of the front of a lower jaw, and from the figure and notice of the animal, measuring nine feet in length, recently forwarded to him by Colonel Grayson. It is very interesting as proving that this genus is found in the North Pacific. The account and figure of Dr. Gill are so very like that of Kogia MacLeayi that I should not bo at all surprised if Kogia breviceps from the Cape of Good Hope, Kogia MacLeayii from Australia (which has been proved not to be distinct from the skull of Physeter simus from the east coast of India), and Eogia Floweri from Mazatlan are all the same species, naturally inhabiting, like the sperm-whale, the tropical regions and wandering to the north and south, as the same species has been found on both sides of the equator.

From the comparison of the photographs which Mr. Krefft sent me, with the skull from Madras (described by Professor Owen) in the British Museum, I could find no difference, as stated in the 'Catalogue of Seals and Whales in the British Museum,' 1866, p. 392; and the comparison of the skulls since sent by Mr. Krefft has established the identity of the Australian specimens from the south and Indian from the north of the equator. Dr. Gill, having overlooked this observation (published in 1866), observes that a generic name will sooner or later be desired for Kogia simus from Madras, and therefore proposes to eall it Callignathus simus (p. 738)-and copies Owen's figure of the young skull (p. 741, figs. 168-171), which is not to be confounded with the skeleton that Professor Owen copies from Krefft's photograph of Euphysetes Grayii, quite a distinct whale of the same group.

On the Development of the Phragmostracum of the Cephalopoda, and on the Zoological Relations of the Ammonites to the Spirulæ. By M. Munigr-Chathas.

I have the honour to submit to the Academy the results of the observations which I have made on the development of the phragmostracum of the Cephalopoda in the laboratory of palæontological research at the Sorbonne, under the guidance of M. Hébert.

This comparative embryogenic investigation proves very clearly that the Ammonites are not tetrabranchiate Cephalopoda allied to the Nautili, as is generally supposed, but dibranchiate decapod Cephalopoda, having the greatest affinity to the Spirula.

As early as 1867 M. J. Barrande had proved, in his great work on the Silurian system of Central Bohemia, the small resemblance that exists between the Goniatites and the Nautilidæ during the first period of their development. In fact, the initial chamber of the phragmostracum of the Cephalopoda of the Nautilide group, except as regards the external cicatrix, does not sensibly differ in its general organization from the other primary chambers which are developed a little later. In speaking of Cyrtocerts M. Barrande moreover expresses himself as follows:--" We shall also call attention to the 
fact that this form of the origin of the shell, which occurs also in Orthoceras, appears to be similar in all the types of Nautilidæ in which we have observed it hitherto. It contrasts, on the ofher hand, with the origin of the shell of the Goniatites, which appears in the form of an egg, isolated from the first air-chamber by a distinct constriction."

This initial chamber (ovisac) of the Goniatites, so different from those which immediately succeed it, is met with at the origin of the phragmostracum of all the dibranchiate Cephalopoda that I have been able to study.

The new and very interesting investigations carried on at Philadelphia by Mr. Hyatt, upon the embryogeny of the phragmostracum of Nautilus pompilius, Derocercas planicosta, and the Goniatites, come in support of these observations. It must be added, however, that Mr. Hyatt, preoccupied by his theoretical ideas upon the evolution of living creatures, in order to establish the filiation of the Ammonites and Nautili, supposes that the latter lost their ovisac by truncation. To support this supposition, he adduces the transverse external cicatrix which he observed on the initial chamber of Nautilus pompilius.

The numerous observations which I have since been able to make upon the termination of the siphon in Aturia zigzag, in the Jurassic, Cretaceous, and Tertiary Nautili, and in the three existing species, the microscopic examination of a transverse section of the initial chamber of Nautilus pompilius and $N$. umbiticatus, and a careful comparison of those Silurian Cephalopoda which lose the extremity of their phragmostracum by truncation have led me to a result completely opposed to the theoretical views put forward by Mr. Hyatt, but conformable in all points with the facts observed by M. Barrande.

The comparative examination which $I$ have made of the ovieacs of Spirula Peronii and of Ammonites Parkinsoni, A. ooliticus, $A$. mamillaris, \&c. has shown me the relations which exist between these two types during their embryonic evolution. In fact, in the Spirulce and the Ammonites the siphon originates in the ovisac a little before the appearance of the first septum. It cornmences by a cæcal inflation, which bears the prosiphon in its prolongation. The new organ to which I give the name of prosiphon must take the place of the siphon during the embryonic period. It originates in the ovisac, opposite the siphonal inflation, upon which it terminates, but without having any internal communication therewith. It is very variable in its general form, and may present a strongly marked example of dimorphism in the same species of Ammonite. It is formed by a membrane, which is sometimes simply spread out as in Spirula Peronii, or which may form a more or less circular tube. It also sometimes presents two, three, or four small subdivisions at its point of insertion upon the inner wall.

I have ascertained the presence of an ovisac in the genera Belemnites, Belemnitella, Beloptera, Belopterina, Spirulirostra, Ammonites, and Ceratites. In Deroceras, Clymenia, and Goniatites its 
general form and its relations with the siphon are the same as in all the Ammonites. It is generally spheroidal when the turns of the spire are free, and ovoid when they are contiguous.

In the tetrabranchiate Cephalopoda which live in our present seas and in all those which swarmed by thousands in the ancient seas, the presence of an ovisac has never been detected. In Nautilus and Aturia the siphon originates upon the inner walls of the first chamber. It is completely closed at its posterior extremity by a part of the calcareous prolongation of the septum which assists in its formation. The external transverse cicatrix observed by $\mathrm{Mr}$. Hyatt can never have been in communication with the siphon; its purpose is still completely unknown. It has been indicated by M. Barrande upon a great number of Silurian Tetrabranchiata.

Thus it results from these observations that at the Silurian epoch the tetrabranchiate Cephalopoda were as clearly separated from the dibranchiate as at the present day. The only modifications that we can recognize are of generic rank; in fact the Ammonites which, when young, have septa like those of Deroceras and Goniatites, appear to be derived from one of those types.-Comptes Rendus, December 29, 1873, pp. 1557-1559.

On the Endomycici. By the Rev. H. S. Gorian.

\section{T'o the Editors of the Annals and Magazine of Natural History.}

Gentuemen,-My attention has been called to a brief notice you have given of my descriptive catalogue of the Endomycici. The question of classification, I venture to submit, is rather an experimental than a logical one, and must be influenced by the amount of knowledge possessed of the objects to be classified; so that a group of genera which fifteen years ago were united into a family may now, by the addition of fresh genera, require subdividing into a group of families; and yet it may be convenient to retain as nearly as possible the original title for the whole group, though of course the patronymic termination must be altered.

Had the reviewer, however, been acquainted with Gerstäcker's 'Entomographien,' he would have known that that author recognized two 'groups,' "zwei sehr ungleiche Gruppen"-I. Endomychidæ genuini, II. Endomychidæ adsciti.

Whether it is illogical to attempt the union of these, or unnecessary to reconstruct the latter (which is a heterogeneous miscellany), I will leave to those who follow me to determine.

As your reviewer is so hard to please in the selection of names, he should at least have quoted correctly the one he terms awkward. I have no family " Paussidoidæ," but one Paussoïdeidæ.

The only genus in this family is Trochoïdeus, Westw. Would he have thought Trochoïdeidœ less awkward or more expressive?

I am, Gentlemen, yours truly,

Shipley, January 19, 1874.

H. S. Gontax. 